\title{
A FACILE METHOD TO PREPARE SUPER-HYDROPHOBIC SURFACES ON SILICONE RUBBERS
}

\author{
PREPROSTA METODA ZA PRIPRAVO SUPERHIDROFOBNIH \\ POVRŠIN PRI SILIKONSKIH GUMAH
}

\author{
Hai Yun Jin'1, Yu Feng Li ${ }^{1}$, Shi Chao Nie', Peng Zhang1, Nai Kui Gao¹, Wen Li \\ ${ }^{1}$ Xi' an Jiaotong University, State Key Laboratory of Electrical Insulation and Power Equipment, Xi' an, 710049, China \\ ${ }^{2}$ Hubei Polytechnic University, Hubei Key Laboratory of Mine Environmental Pollution Control \& Remediation and School of Chemical and \\ Materials Engineering, Huangshi, 435003, PR China \\ 1xfzzl@126.com \\ Prejem rokopisa - received: 2016-09-02; sprejem za objavo - accepted for publication: 2016-10-24
}

Fabricating large-scale super-hydrophobic surfaces for commercial applications is challenging due to certain limitations. In this paper, a simple and inexpensive method is developed to fabricate super-hydrophobic surfaces on silicone rubbers. Rough microstructures were prepared on the mould's inner surfaces and then sample super-hydrophobic surfaces on silicone rubbers with different surface roughness were achieved using the standard moulding process. Furthermore, the effects of roughness on the wettability were investigated. The results showed that by controlling the roughness, the fabricated surfaces exhibited a static contact angle of $150.9^{\circ}$ and a sliding angle of $8^{\circ}$. Finally, the property of hydrophobicity recovery for the silicone-rubber samples was also studied. The surfaces of the samples could recover well after a sand-blasting experiment. The proposed method is low-cost, environmentally friendly and suggests promising industrial applications.

Keywords: thin films, coatings, chemical techniques, surface properties

Izdelava obsežnih superhidrofobnih površin za komercialne namene je zaradi določenih omejitev zahtevna. V članku je razvit preprost in poceni način za izdelavo superhidrofobne površine na silikonskih gumah. Grobe mikrostrukture so bile pripravljene na notranjih površinah kalupa in nato je bila dosežena vzorčna superhidrofobna površina na silikonski gumi z različno hrapavo površino z uporabo standardnega postopka modeliranja. Nadalje so bili raziskani učinki hrapavosti na omočljivost. Rezultati so pokazali, da so s krmiljenjem hrapavosti izdelane površine razstavljene pod statičnim kontaktnim kotom $150.9^{\circ}$ in drsnim kotom $8^{\circ}$. Nazadnje je bila preučevana tudi lastnost okrevanja hidrofobnosti vzorcev silikonskih gum. Površine vzorcev se lahko dobro obnovijo tudi po poskusu s peskanjem. Predlagana metoda je poceni, okolju prijazna in kaže obetavne možnosti apliciranja $v$ procese $\mathrm{v}$ industriji.

Ključne besede: tanke plasti, prevleke, kemijske tehnike, površinske lastnosti

\section{INTRODUCTION}

Superhydrophobic surfaces, with a water contact angle (CA) greater than $150^{\circ}$ and a sliding angle (SA) less than $10^{\circ}$, have aroused increasing research interest for their promising applications. ${ }^{1-6}$ By observing the microstructure of a lotus leaf surface, it was found that the combination of micro papilla and a thin wax film leads to the self-cleaning properties. ${ }^{4} \mathrm{~L}$. Jiang et al. ${ }^{1}$ discovered that on top of the micro papilla also exist branch-like nanostructures and pointed out that the micro- and nanoscale hierarchical structures were the fundamental mechanism for lotus leaf's unique wetting properties. There were two main measures to fabricate superhydrophobic surfaces:

1) preparation of a rough surface followed by a low free-energy material coating step,

2) creation of a rough surface from low-surface-energy materials. ${ }^{1}$

Up to now, many approaches to fabricate rough surfaces had been developed, including the template method $^{7}$, phase separation ${ }^{8}$, self-assembly ${ }^{9}$, vapour-phase deposition ${ }^{10}$, chemical etching ${ }^{11}$, laser etching ${ }^{12}$, hydro- thermal method ${ }^{13}$, and electrospinning ${ }^{14}$. In the power system, the surfaces of insulators always work under high voltage and the sand-dust climate condition. However, some superhydrophobic coats (especially rubberbased coatings) synthesized by techniques on large-area and environmentally friendly cannot meet the operating requirements of composite insulators. ${ }^{15-17}$ Therefore, it is a good way to solve this problem by synthesizing a superhydrophobic surface on the basis of not changing the insulator material. Silicon rubber was a hydrophobic material; therefore, a superhydrophobic surface could be created by only forming a special $\mathrm{nm}-\mu \mathrm{m}$ geometry structure. The template method was a simple and convenient technique that could be used as a method to prepare superhydrophobic surfaces, and the quality of this method was easy to control; therefore, template method was suited for industrial production.

In this study, to fabricate a superhydrophobic surface on the composite insulators, a silicone-rubber superhydrophobic surface was developed with a facile template method. The creation of a rough structure on the inner surface of the mould and a special geotroy morphology was prepared on the silicone-rubber surface 


\section{H. Y. JIN et al.: A FACILE METHOD TO PREPARE SUPER-HYDROPHOBIC SURFACES ON SILICONE RUBBERS}

through a conventional moulding process. The surface microstructures were investigated by a roughness tester and scanning electron microscope (SEM). It was found that the superhydrophobic silicone-rubber surface could be attained by creating the appropriate roughness surfaces, which lead to the lotus-leaf-like surface morphology. After samples suffered the artificial sandstorm testing, the property of hydrophobicity recovery for superhydrophobic and a common silicone-rubber surface have also been studied in this paper.

\section{EXPERIMENTAL PART}

Templates with different rough structures were prepared first. Silicon carbide particles of $(63,21,15$, and 10.5) $\mu \mathrm{m}$ in diameter were obtained by using test sieves of $80,240,600,800$ and 1200 mesh, respectively. A uniform layer of resin binder-epoxy resin was sprayed on the inner surface of a cubic mould with dimensions of 3 $\mathrm{cm} \times 3 \mathrm{~cm} \times 3 \mathrm{~cm}$ after treating with a silane coupling agent $\mathrm{N}$ - $\beta$-aminoethyl- $\gamma$-aminopropyl trimethoxysilane. The prepared silicon carbide particles were evenly sprayed on the inner surface of the mould and dried at room temperature. Then rough silicon rubber samples were prepared through a conventional moulding process. Liquid silicone rubber was poured into the mould, the mould was taken off after consolidation, and thus silicone-rubber surfaces with different surface morphologies were obtained. To avoid the superhydrophobic surface being destroyed during the mould unloading, the moulds were treated with a release agent(methyl-silicone oil). For a comparison, the smooth silicone rubber was prepared with a smooth mould.

To analyses the morphology and microstructures of the sample surfaces, SEM and a roughness tester were used. The morphological characterization was observed with a SEM (VE-9800, Keyence). The surface roughness $R_{\mathrm{a}}$ was measured with a handhold roughness tester (TR200, Times Run Bao). The roughness tester was placed at 20 different locations of the sample surface under investigation and the average value was taken as the surface roughness.

The water contact angles were investigated using a measurement system (JC2000C4, POWEREACH). Before the test the samples were washed with deionized water and ethanol, respectively, and then naturally dried. Five different locations of the sample surface were measured, and the average value was used.

The property of hydrophobicity recovery for both the superhydrophobic and the common silicone-rubber surface were tested in the artificial experimental platform, and the sand-dust sample was also prepared, as described in ${ }^{18}$. Samples of superhydrophobic silicone rubber and the common silicone rubber were placed horizontally in the experimental platform. The surfaces of the samples and the wind direction were parallel. The wind speed was $15 \mathrm{~m} / \mathrm{s}$. The samples were in the artificial sandstorm for $1 \mathrm{~h}$. To accelerate the process of hydrophobicity recovery, the heat treatment for the sample was carried out in an oven at $75^{\circ} \mathrm{C}$.

\section{RESULTS AND DISCUSSION}

Figure 1a to 1f show SEM micrographs of surface morphologies for the different silicone-rubber surfaces. A very flat microstructure can be seen from the surface prepared with the smooth template (Figure 1a). After preparing with templates, the surfaces have spongy-like rough structures and this confirmed that the morphology of the mould surface was successfully replicated. It can be seen that rough structure units (number and decrease in scale) increase with decreasing silicon carbide particle size. The silicone-rubber surface prepared with a template of particle size $63 \mu \mathrm{m}$ has an average diameter of $200 \mu \mathrm{m}$ irregular protuberances and pits (Figure 1b), the surface distributes on average a diameter of $100 \mu \mathrm{m}$ irregular papilla (Figure 1c), and the surface prepared with template of particle size of $15 \mu \mathrm{m}$ in diameter has a diameter of about $40 \mu \mathrm{m}$ irregular pits and protuberances (Figure 1d). Figure 1e to 1f are higher-resolution micrographs of Figure 1d. Figure 1f and show that the randomly distributed papilla morphology (observed in Figure 1e) consists of sub-micron structures, which implies two-length-scale hierarchical structure on the surface. Therefore, the Cassie-Baxter superhydrophobic state was well formed.
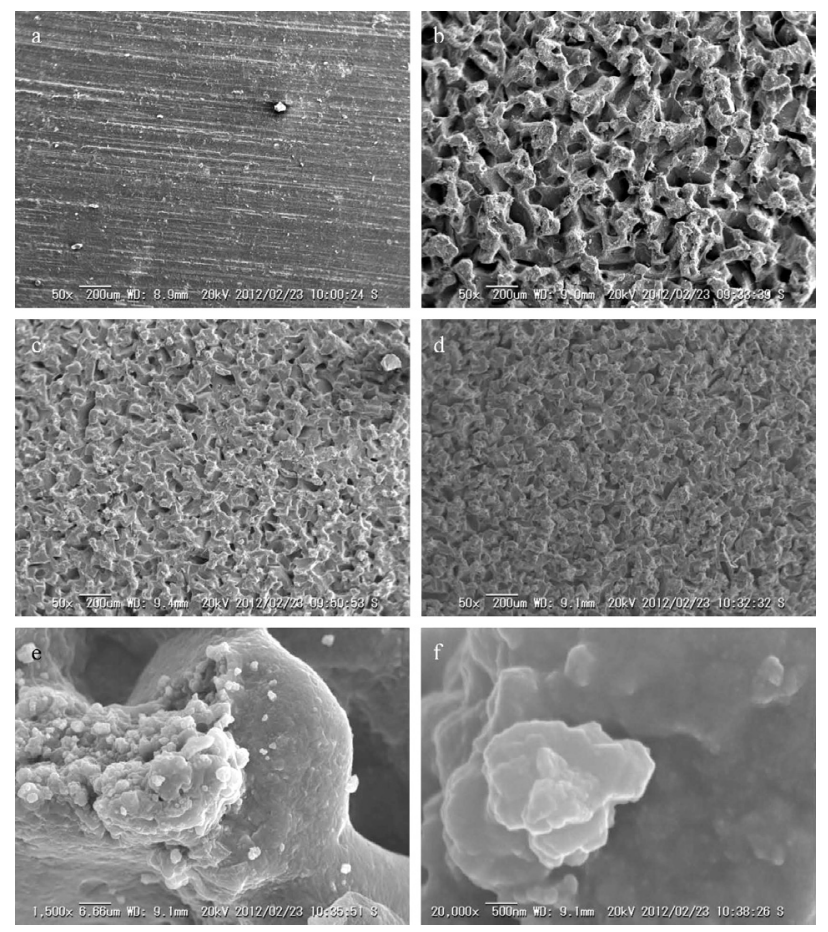

Figure 1: SEM micrographs of surface prepared with templates of different diameter silicon carbide particles: a) smooth, b) $63 \mu \mathrm{m}$, c) $21 \mu \mathrm{m}$, d) $15 \mu \mathrm{m}$, e) the high magnification of d), and f) the high magnification of (e) 


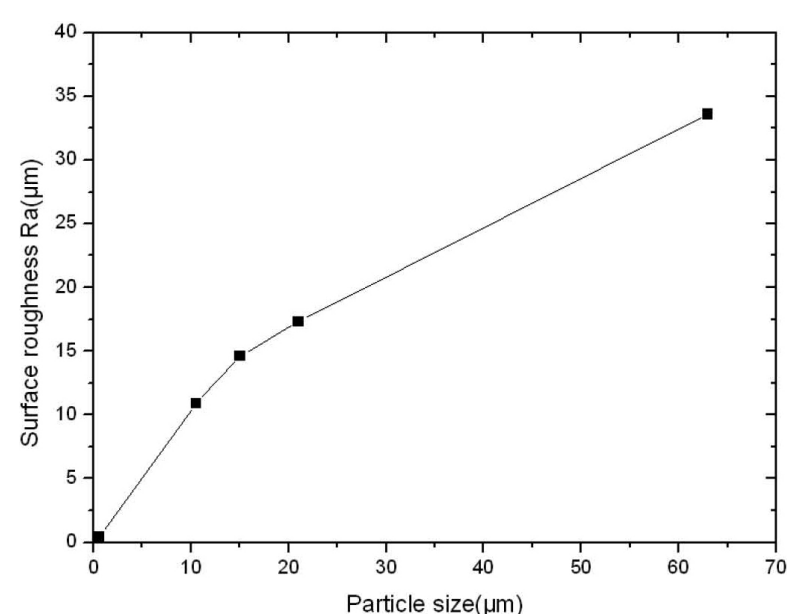

Figure 2: Relationship between particle size and surface roughness $R_{\mathrm{a}}$

Figure 2 shows the roughness of the surface morphology. The surface roughness of the smooth silicone rubber surface was $0.42 \mu \mathrm{m}$. When the templates are made by different silicon carbide particles of $(10.5,15$, 21 , and 63$) \mu \mathrm{m}$ in diameter, the surface roughness of the samples made by different templates are (10.88, 14.63, 17.32 and 33.61) $\mu \mathrm{m}$, respectively. The results show that, after roughening with a rough template, the surface roughness of the silicone rubber increases with the increasing particle size of the sprayed silicon carbide.

Figure 3 shows the relationship between the surface wettability and the surface roughness. It is clear that the contact angle of the smooth silicone rubber surface is $110.2^{\circ}$ and the sliding angle is about $90^{\circ}$. While roughening with rough templates, the surface wettability is greatly improved (the contact angle is larger than $140^{\circ}$ and the sliding angle is from $8^{\circ}$ to $50^{\circ}$ ). The higher contact angle of the rough silicone-rubber surface can be attributed to the formation of the Wenzel wetting state (Figure 4a). According to Wenzel model $\left(\cos \theta^{*}=r \cos \right.$ $\theta$, where $\theta^{*}$ is Wenzel apparent contact angle, $\theta$ is the intrinsic contact angle of the ideal smooth material,

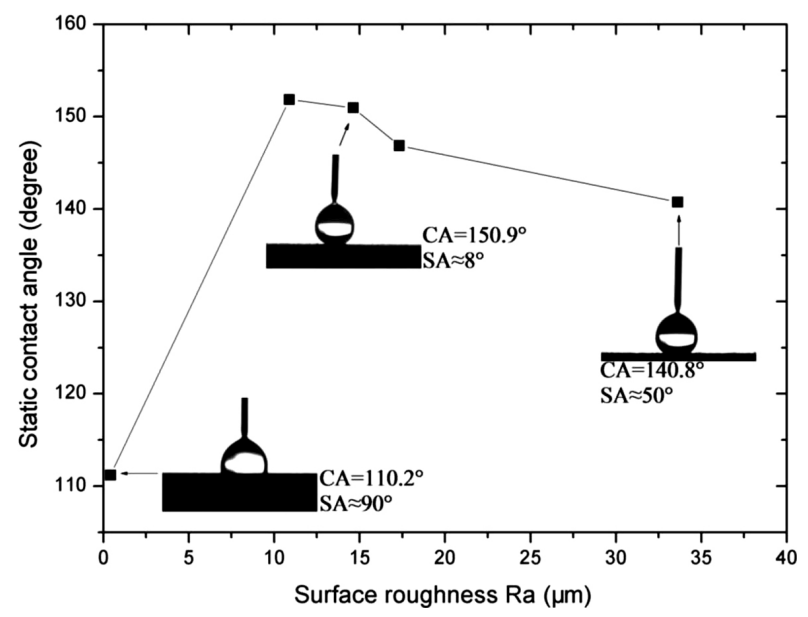

Figure 3: Relationship between static contact angle and surface roughness which also called as Young's contact angle, and $r$ is the ratio of the actual area to the projected area), rough structures can amplify the natural wettability tendency of the surface. Since silicone rubber is hydrophobic, the surface hydrophobic property will be improved by roughening the surface; its new contact angle becomes greater than the intrinsic contact angle. The contact angle reaches to $150.9^{\circ}$ with a very small sliding angle of $8^{\circ}$ for samples with a surface roughness of $14.63 \mu \mathrm{m}$. This can be explained by the formation of the Cassie-Baxter wetting state (Figure $\mathbf{4 b}$ ), for it has a lotus-leaf-like surface morphology (Figure 1d to 1f). It is because of that that there is such a micro-submicron hierarchical structure on samples, which is like the structure of the lotus leaf. ${ }^{1,4}$ If a water droplet is placed upon the surface, air can be entrapped in both the hollows and interstices, resulting in the formation of a high area fraction of air-liquid interfaces. According to the Cassie-Baxter equation $\left(\cos \theta_{\mathrm{a}}=f_{1} \cos -f_{2}\right.$, where $\theta_{\mathrm{a}}$ is the apparent contact angle on a rough surface, $f_{1}$ is the area fraction of the solid-liquid interface, and $f_{2}$ is area fraction of the air-liquid interface), the contact angle can larger than $150^{\circ}$ when the rough surface attains a large area fraction of air-liquid interface. With regards to the sliding angle, a surface exhibiting the Wenzel wetting state usually shows a larger sliding angle due to the pinning effects (Figure 4a). In contrast, a surface following the regime of the Cassie-Baxter wetting state (Figure 4b) allows a water droplet to roll off easily with a sliding angle of less than $10^{\circ}$.

Figure 3 shows that surface roughness plays an important role in the surface wettability. Since all the silicone rubber samples are prepared with a similar template structure (but different roughness), the samples present a similar surface morphology (Figure $\mathbf{1 b}$ to $\mathbf{1 d}$ ). For samples with surface roughness $R_{\mathrm{a}}$ of $10.88 \mu \mathrm{m}$ and $14.63 \mu \mathrm{m}$, the contact angle exceeds $150^{\circ}$, with a negligible sliding angle of about $8^{\circ}$. The contact angles reaches to a maximum value of $151.8^{\circ}$, when the surface roughness is $10.88 \mu \mathrm{m}$. When the surface roughness is larger than $10.88 \mu \mathrm{m}$, the contact angles decrease with increasing surface roughness. For the samples with a surface roughness $\left(R_{\mathrm{a}}\right)$ of $17.32 \mu \mathrm{m}$ and $33.61 \mu \mathrm{m}$, the contact angles are $146.9^{\circ}$ and $140.8^{\circ}$ respectively, while both of them show a sliding angle of about $50^{\circ}$. It is known that the micro-scale and nano-scale hierarchical structures affect the contact angle greatly. The microscale and nano-scale hierarchical structures can be

\section{HIIII HIIII HHHII}

Figure 4: Various wetting state model sketch of a droplet on a rough surface: a) Wezel state, b) Cassie-Baxer state and c) combined Cassie-Baxter/Wenzel state 


\section{H. Y. JIN et al.: A FACILE METHOD TO PREPARE SUPER-HYDROPHOBIC SURFACES ON SILICONE RUBBERS}

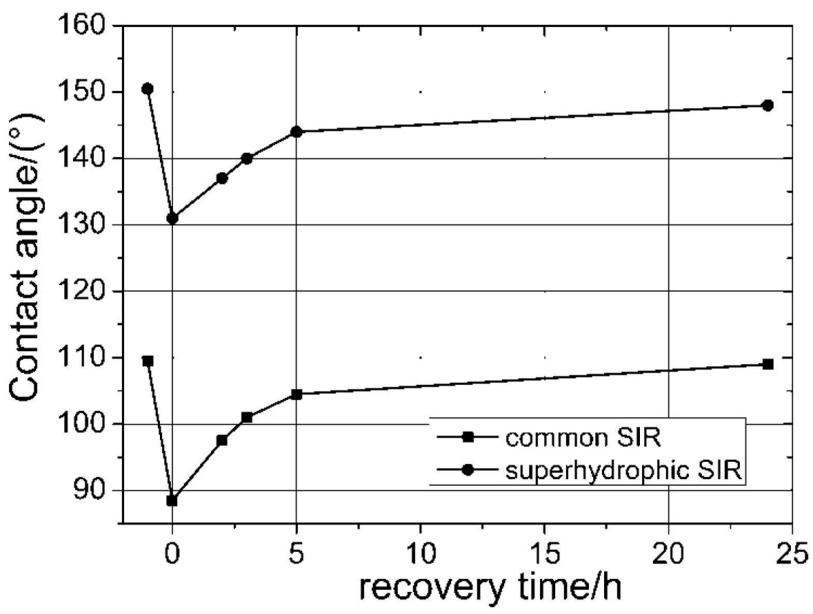

Figure 5: The recovery curve for the hydrophobicity of the silicone-rubber samples

quantified by the surface roughness; therefore, the effect of surface structures on the contact angle can be studied by the surface roughness. ${ }^{19}$ Compared with the contact angle, the sliding angle is more affected by the surface roughness. This can be attributed to the formation of the combined Cassie-Baxter and Wenzel wetting state model (Figure 4c). ${ }^{20,21}$ As seen, the area fraction of air-liquid interfaces from the combined Cassie-Baxter and Wenzel wetting state model changes little (compared with Cassie-Baxter wetting state model); therefore, the contact angle will be larger than $140^{\circ}$. However, the sliding angle is greatly increased due to a certain extent by the pinning effects (Figure 4c). With respect to promising applications, such as anti-icing of superhydrophobic surfaces, both the contact angle and the small sliding angle are very important; therefore, the sliding angle also plays a important role. ${ }^{22}$ Superhydrophobic surfaces with negligible sliding angle can be obtained by controlling the surface structure and the roughness.

Figure 5 shows the changes of the contact angle after the sandstorm experiment and the hydrophobicity recovery experiment. Because of the effects of the sand-dust, both of the contact angles decrease by approximately $20^{\circ}$. At the beginning of the recovering process, the hydrophobicity of samples recover quickly. Then the speed of the recovery slows down. After $24 \mathrm{~h}$ in a high-temperature treatment, the hydrophobicities of both superhydrophobic and common silicone rubber have basically recovered to the level of the primary sample.

The sand-dust on the silicone rubber is hydrophilic, which results in hydrophobicity degradation of the samples. Inside the silicone rubber, the large molecules polysiloxane are cracked into smaller molecules polysiloxane. And the high temperature can accelerate the cracking process. The small molecules polysiloxane with a low surface tension can migrate to the surface of the silicone rubber and cover the sand-dust particles. ${ }^{23,24}$ Therefore, the hydrophobicity can be recovered after the high-temperature treatment. Considering that the contact angle of the superhydrophobic silicone rubber has recovered to almost $150^{\circ}$, it shows that the micro-submicron hierarchical structure of superhydrophobic surfaces can almost not be destroyed.

\section{CONCLUSIONS}

Superhydrophobic surfaces were successfully fabricated on silicone rubbers through a facile template method. The contact angle for the surfaces can reach a maximum of $151.8^{\circ}$ (sliding angle about $8^{\circ}$ ) with a surface roughness of $10.88 \mu \mathrm{m}$. When the surface roughness is larger than $10.88 \mu \mathrm{m}$ the contact angle decreased with increasing roughness, and when the surface roughness is less than $10.88 \mu \mathrm{m}$, the contact angle increased with increasing roughness. The micro/sub-micron hierarchical structures of the surface were responsible for the high water contact angle and the low sliding angle. The wetting ability of the various surface roughness was different, and it could be explained by the different wetting state model. The sandstorm testing and the hydrophobicity experiment showed that the contact angle of both superhydrophobic and the common silicone rubber sample could recover.

\section{Acknowledgments}

This research was financially supported by the National Natural Science Foundation of China (No. 51272208), the Natural Science Foundation of Hubei Province (2010CDA026), the Key Program of Hubei Provincial Department of Education (Z20104401), the Outstanding Scientific and Technological Innovation Team Project of Universities in Hubei Province (T201423), and the Talent Program of Hubei Polytechnic University (11yjz04R).

\section{REFERENCES}

${ }^{1}$ L. Feng, S. Li, Y. Li, H. Li, L. Zhang, J. Zhai, Y. Song, B. Liu, L. Jiang, D. Zhu, Super-hydrophobic surfaces: From natural to artificial, Advanced Materials, 14 (2002) 24, 1857-1860, doi:10.1002/adma. 200290020

${ }^{2}$ K. K. Varanasi, M. Hsu, N. Bhate, W. Yang, T. Deng, Spatial Control in the Heterogeneous Nucleation of Water, Applied Physics Letters, 95 (2009) 9, 094101, doi:10.1063/1.3200951

${ }^{3}$ L. Cao, A. K. Jones, V. K. Sikka, J. Z. Wu, D. Gao, Anti-Icing Superhydrophobic Coatings, Langmuir, 25 (2009) 21, 12444-12448, doi:10.1021/la902882b

${ }^{4}$ W. Barthlott, C. Neinhuis, Purity of the sacred lotus, or escape from contamination in biological surfaces, Planta, 202 (1997) 1, 1-8, doi:10.1007/s004250050096

${ }^{5}$ F. Arianpour, M. Farzaneh, S. A. Kulinich, Hydrophobic and ice-retarding properties of doped silicone rubber coatings, Applied Surface Science, 265 (2013), 546-552, doi:10.1016/j.apsusc.2012.11.042

${ }^{6}$ J. Li, Y. Zhao, J. Hu, L. Shu, X. Shi, Anti-icing Performance of a Superhydrophobic PDMS/Modified Nano-silica Hybrid Coating for Insulators, Journal of Adhesion Science and Technology, 26 (2012) 4-5, 665-679, doi:10.1163/016942411X574826 


\section{MATERIALI IN TEHNOLOGIJE/MATERIALS AND TECHNOLOGY (1967-2017) - 50 LET/50 YEARS}

\section{H. Y. JIN et al.: A FACILE METHOD TO PREPARE SUPER-HYDROPHOBIC SURFACES ON SILICONE RUBBERS}

${ }^{7}$ M. Jin, M. Liao, J. Zhai, L. Jiang, Super-hydrophobic polystyrene films prepared via pattern transformation, Acta Chimica Sinica, 66 (2008) 1, 145-148, doi:10.3321/j.issn:0567-7351.2008.01.025

${ }^{8}$ Q. Xie, G. Fan, N. Zhao, X. Guo, J. Xu, J. Dong, L. Zhang, Y. Zhang, C. Han, Facile creation of a bionic super-hydrophobic block copolymer surface, Advanced Materials, 16 (2004) 20, 1830-1833, doi:10.1002/adma.200400074

${ }^{9}$ J. Genzer, K. Efimenko, Creating long-lived super-hydrophobic polymer surfaces through mechanically assembled monolayers, Science, 290 (2000) 5499, 2130-2133, doi:10.1126/science.290.5499.2130

${ }^{10}$ A. Hozumi, O. Takai, Preparation of ultra water-repellent films by microwave plasma-enhanced CVD, Thin Solid Films, 303 (1997) 1-2, 222-225, doi:10.1016/S0040-6090(97)00076-X

${ }^{11}$ D. Xie, W. Li. A novel simple approach to preparation of superhydrophobic surface of aluminum alloys, Applied Surface Science, 258 (2011) 3, 1004-1007, doi: 10.1016/j.apsusc.2011.07.104

${ }^{12}$ T. Sun, G. Wang, L. Feng, B. Liu, Y. Ma, L. Jiang, D. Zhu, Reversible switching between super-hydrophilicity and super-hydrophboicity, Angewandte Chemie International Edition, 43 (2004) 3, 357-360, doi:10.1002/anie.200352565

${ }^{13}$ X. Feng, L. Feng, M. Jin, J. Zhai, L. Jiang, D. Zhu, Reversible super-hydrophobicity to super-hydrophilicity transition of aligned $\mathrm{ZnO}$ nanorod films, Journal of the American Chemical Society, 126 (2004) 1, 62-63, doi:10.1021/ja038636o

${ }^{14}$ L. Jiang, Y. Zhao, J. Zhai, A lotus-leaf-like superhydrophobic surface: a porous microsphere/nanofiber composite film prepared by electrohydrodynamics, Angewandte Chemie International Edition, 43 (2004) 33, 4338-4341, doi:10.1002/anie.200460333

${ }^{15}$ M. K. Tiwari, I. S. Bayer, G. M. Jursich, T. M. Schutzius, C. M. Megaridis, Highly Liquid-Repellent, Large-Area, Nanostructured Poly(vinylidene fluoride)/Poly(ethyl 2-cyanoacrylate) Composite Coatings: Particle Filler Effects, ACS applied materials \& interfaces, 2 (2010) 4, 1114-1119, doi:10.1021/am900894n

${ }^{16}$ T. M. Schutzius, I. S. Bayer, J. Qin, D. Waldroup, C. M. Megaridis, Water-Based, Nonfluorinated Dispersions for Environmentally Benign, Large-Area, Superhydrophobic Coatings, ACS applied materials \& interfaces, 5 (2013) 24, 13419-13425, doi:10.1021/ am4043307
${ }^{17}$ E. Bormashenko, V. Goldshtein, R. Barayev, T. Stein, G. Whyman, R. Pogreb, Z. Barkay, D. Aurbach, Robust method of manufacturing rubber waste-based water repellent surfaces, Polymers for Advanced Technologies, 20 (2009) 7, 650-653, doi:10.1002/pat.1323

${ }^{18}$ B. He, G. Zhang, B. Chen, N. Gao, Y. Li, Z. Peng, H. Jin, The influence of the sand-dust environment on air-gap breakdown discharge characteristics of the plate-to-plate electrode, Science China Physics, Mechanics and Astronomy, 53 (2010) 3, 458-464, doi:10.1007/s11433-010-0078-1

${ }^{19}$ X. Shi, T. A. Nguyen, Z. Suo, J. Wu, J. Gong, R. Avci, Electrochemical and mechanical properties of superhydrophobic aluminum substrates modified with nano-silica and fluorosilane, Surface and Coatings Technology, 206 (2012) 17, 3700-3713, doi:10.1016/j.surfcoat. 2012.02.058

${ }^{20} \mathrm{X}$. Feng, L. Jiang, Design and creation of superwetting/antiwetting surfaces, Advanced Material, 18 (2006) 23, 3063-3078, doi:10.1002/ adma.200501961

${ }^{21}$ C. W. Yang, F. He, P. F. Hao, The apparent contact angle of water droplet on the micro-structured hydrophobic surface, Science China Chemistry, 53 (2010) 4, 912-916, doi:10.1007/s11426-010-0115-y

${ }^{22}$ S. A. Kulinich, M. Farzaneh, How Wetting Hysteresis Influences Ice Adhesion Strength on Superhydrophobic Surfaces. Langmuir, 25 (2009) 16, 8854-8856, doi:10.1021/la901439c

${ }^{23}$ J. W. Chang, R. S. Gorur, Surface recovery of silicone rubber used for HV outdoor insulation, IEEE Transactions on Dielectrics and Electrical Insulation, 1 (1994) 6, 1039-1046, doi:10.1109/94.368659

${ }^{24}$ T. Tokoro, R. Hackam, Loss and recovery of hydrophobicity and surface energy of HTV silicone rubber, IEEE Transactions on Dielectrics and Electrical Insulation, 8 (2001) 6, 1088-1097, doi: $10.1109 / 94.971469$ 